\title{
Scientific Rigor and Contemporary Educational Technology
}

\author{
Michael Simonson \\ Nova Southeastern University, United States
}

Three quotes are central to the development and growth of the field of educational technology. These statements represented the themes of classic articles written by leaders in education and remain today as guides for the field.

The first was by James Finn, one of the founders of the modern educational technology field. In 1953, in the introductory issue of Audio-Visual Communication Review, he wrote:

Finally, the most fundamental and most important characteristic of a profession is that the skills involved are founded upon a body of intellectual theory and research. Furthermore, this systematic theory is constantly being expanded by research and thinking within the profession. As Whitehead says, "...the practice of a profession cannot be disjoined from its theoretical understanding and vice versa.... The antithesis to a profession is an avocation based upon customary activities and modified by the trial and error of individual practice. Such an avocation is a Craft..." (Smith et al., 1951, p. 557). The difference between the bricklayer and the architect lies right here. (p. 8)

The second quote is by Campbell and Stanley, who, in their classic 1963 monograph, described the experiment

...as the only means for settling disputes regarding educational practice, as the only way of verifying educational improvements, and as the only way of establishing a cumulative tradition in which improvements can be introduced without the danger of a faddish discard of old wisdom in favor of inferior novelties. (p. 2)

The final quote is the controversial statement from the Review of Educational Research made by Richard Clark in 1983:

The best current evidence is that media are mere vehicles that deliver instruction but do not influence student achievement any more than the truck that delivers our groceries causes changes in nutrition...only the content of the vehicle can influence achievement. (p. 445)

Finn attempted to encourage those in the audio-visual field to take a more professional view of themselves and their discipline by basing decisions on theory supported by research. Campbell and Stanley formalized what previously had been unclear to many-the need for the rigorous 
application of the scientific method to the study of education. Twenty years later in 1983, Richard Clark identified why Campbell and Stanley's admonition was so important. His article documented the failure of many educational researchers to "verify educational improvements, as demanded by Campbell and Stanley" (p. 2). Clark's article was not popular. However, it clearly and precisely showed how researchers had violated basic guidelines for rigorous research, which had led many educators to adopt "inferior novelties" at the expense of scientifically-validated "wisdom."

Each of these scholars had a message of critical importance to educational technology-scientific inquiry, conducted with rigorous attention to correct procedures, is the key to success of our field. Research and theory are at the foundation of credibility and quality.

Unfortunately, many still do not appreciate the importance of studying educational innovations using the appropriate application of the scientific method. If education generally, and educational technology specifically, are to move from the realm of a craft to that of a profession, the need for scientific rigor must be a defining priority at the foundation of our decisions. Journals such as Contemporary Educational Technology will lead the quest for this goal.

\section{References}

Campbell, D., \& Stanley, J. (1963). Experimental and quasi-experimental designs for research. Boston: Houghton Mifflin.

Clark, R. (1983). Reconsidering research on learning from media. Review of Educational Research, 53(4), 445-459.

Finn, J. (1953). Professionalizing the audiovisual field. Audo-Visual Communication Review, 1(1), 617.

Smith, B., Benne, K., Stanley, W., \& Anderson, A. (1951). Readings in the Social Aspects of Education. Danville, ILL.: Interstate Printers and Publishers.

Correspondence: Michael Simonson, Professor, Instructional Technology and Distance Education, Fischler School of Education and Human Services, Nova Southeastern University, North Miami Beach, FL 33162, United States. 